\title{
THE EFFECT OF PHOSPHOR DOPING ON THE ENHANCEMENT OF AMMONIA GAS SENSING WITH AMMONIUM HYDROGERMANATE SOLID ELECTROLYTES
}

\author{
Nobuhito Imanaka, Senri Yoshikawa, Takao Yamamoto, and Gin-ya Adachi, Non-member \\ (Osaka University)
}

\begin{abstract}
Various types of solid electrolytes based on ammonium hydrogermanate in which the germanium site was partially replaced by phosphor were prepared by a hydrothermal method and the ammonia gas sensing characteristics were investigated by fabricating an ammonia gas concentration cell with the hydrogermanates. The EMF output of the response was greatly improved by forming a solid solution by the phosphor doping with a considerable enhancement of the relative density and also the mechanical strength of the solid electrolytes.
\end{abstract}

Keywords: solid electrolytes, ammonium ion, ammonia, sensor, hydrogermanate, solid solution

\section{INTRODUCTION}

Ammonia gas is one of useful gas species in an industrial point of view. However, the gas is very toxic and once the gas leaks, a serious disaster occurs. For the purpose of preventing such an accident, a smart ammonia gas sensor which can detect the gas rapidly and also selectively is greatly required. In order to realize an exact and a rapid identification of the gas leakage site, a suitable way is to install a certain number of the sensor cell in several sites in each factory. $\mathrm{Up}_{\mathrm{p}}$ to now, two types of $\mathrm{NH}_{3}$ detection method have been already commercialized. One is the electrochemical and the other is the semiconducting method. However, an aqueous electrolyte solution is applied in the former case and this limits the utilization of the sensor in frozen facilities. The sensor with the latter one has an advantage in fabricating the sensor as a compact device. However, the sensors with semiconductors are not suitable for a selective and quantitative detection. A smart $\mathrm{NH}_{3}$ sensor which can overcome such problems mentioned above, has been greatly requested.

High selectivity can be realized when solid electrolytes are used as the component of the sensor, since mobile species is limited to only one ionic species. In addition, most of cases, the sensor output is obtained as an electromotive force(EMF) and a clear 1 to 1 relation can be easily observed in the relationship between the output and the detecting $\mathrm{NH}_{3}$ gas content, suitable for a quantitative detection. Various types of ammonia gas sensors using the solid electrolyte ones ${ }^{1-5)}$ have been proposed. In our previous letter, $\left.{ }^{6}\right)$ we proposed a new type of an ammonia gas sensor composed of ammonium hydrogermanate with phosphor addition. However, the effect of the phosphor doping has not been clarified yet.

In this letter, the effect of phosphor doping on the enhancement of ammonia gas sensing with ammonium hydrogermanate solid electrolyte was explicitly clarified.

\section{EXPERIMENTAL}

Reagent grade of $\mathrm{GeO}_{2},\left(\mathrm{NH}_{4}\right)_{2} \mathrm{HPO}_{4}, \mathrm{NH}_{4}(\mathrm{OH}), \mathrm{H}_{2} \mathrm{O}$, and ethylene glycol were mixed thoroughly in a proper molar ratio. The mixture was heat treated by a hydrothermal synthesis at $180^{\circ} \mathrm{C}$ for $60 \mathrm{~h}$ in a stainless steel vessel to obtain $\left(\mathrm{NH}_{4}\right)_{1,4+x} \mathrm{H}_{1}$ ${ }_{\mathrm{x}} \mathrm{Ge}_{7-\mathrm{y}} \mathrm{P}_{\mathrm{y}} \mathrm{O}_{15} \bullet 6 \mathrm{H}_{2} \mathrm{O}(0<\mathrm{x}<1,0<\mathrm{y}<1.4)$. The powder formed was corrected by a centrifuge method and then washed with methanol(reagent grade) and dried at room temperature. The sample powder was pulverized in an agate mortar and then hot pressed at $100^{\circ} \mathrm{C}$ as a pellet shape under the pressure of $4.8 \times 10^{3}$ $\mathrm{kg} / \mathrm{cm}^{2}$. Silver paste(P-248) from Furuya Metal Cooperation was painted as the electrodes on both center surface(diameter : $6.2 \mathrm{~mm}$ ) of the pellet. The pellet was set between two pyrex glass tubes to investigate the $\mathrm{NH}_{3}$ sensing characteristics of the cell. Ammonia gas diluted with air was passed in each glass tube to work as a $\mathrm{NH}_{3}$ gas concentration cell. The X-ray powder diffraction analysis using $\mathrm{Cu}-\mathrm{K} \alpha$ radiation (M18XHF, Mac Science) was carried out and the XRD data were collected by a step-scanning method for the $2 \theta$ range between $10^{\circ}$ and $70^{\circ}$ with a step width of $0.04^{\circ}$ and a scan speed of $10^{\circ} / \mathrm{min}$. The ICP analysis was also carried out by Shimadzu ICPS-1000IV to determine the accurate Ge to $P$ ratio in the electrolyte solid solutions prepared. Micro Hardness Tester (Shimadzu HMV-2T) was used to determine the hardness of the pellets.

\section{RESULTS AND DISCUSSION}

In the case that solid electrolytes are applied for the gas sensor element, the tightness of the electrolyte is highly required in order to avoid the gas leakage in the cell. Here, the doping of phosphor in $\left(\mathrm{NH}_{4}\right)_{1.4+x} \mathrm{H}_{1 \cdot x} \mathrm{Ge}_{7} \mathrm{O}_{16} \cdot 6 \mathrm{H}_{2} \mathrm{O}(0<\mathrm{x}<1)$ to make a solid solution was carried out in order to enhance the relative density and also the mechanical strength of the solid electrolyte. All samples show similar pattern to that of phosphor undoped one except for the sample of two phase mixture of the mother $\left(\mathrm{NH}_{4}\right)_{3} \mathrm{HGe}_{7} \mathrm{O}_{16} \bullet 6 \mathrm{H}_{2} \mathrm{O}$ phase and a small amount of the $\left(\mathrm{NH}_{4}\right)_{2} \mathrm{HPO}_{4}$ phase. With the increase of the $\mathrm{P}$ amount in the hydrogermanate, the peak angles of the phosphor doped hydrogermanate electrolytes deviate to 


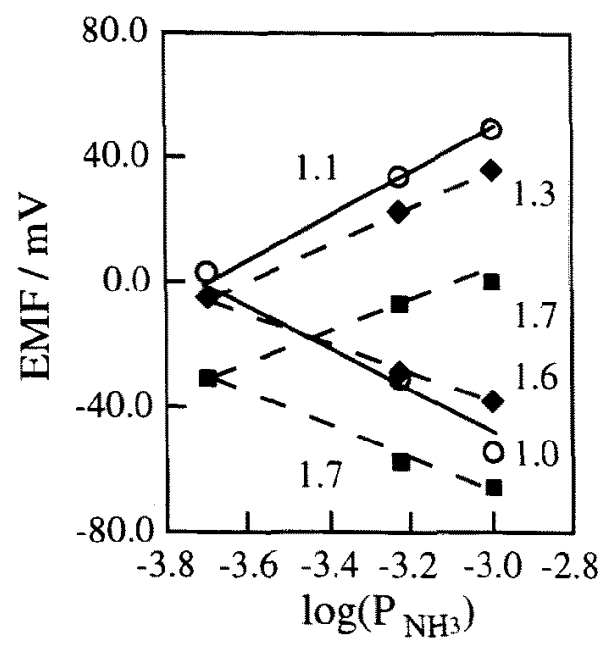

Fig. 1 The variation of the sensor output with the logarithm of the $\mathrm{NH}_{3}$ gas concentration by fabricating the $\mathrm{NH}_{3}$ gas concentration cell at $100^{\circ} \mathrm{C}$ for the solid solution of $\left(\mathrm{NH}_{4}\right)_{1,4+\times} \mathrm{H}_{1}$ ${ }_{x} \mathrm{Ge}_{7} \mathrm{O}_{15} \cdot 6 \mathrm{H}_{2} \mathrm{O}(0<\mathrm{x}<1)(\mathbf{Q}),\left(\mathrm{NH}_{4}\right)_{1,4+\mathrm{x}} \mathrm{H}_{1}$ ${ }_{x} \mathrm{Ge}_{6,0} \mathrm{P}_{10} \mathrm{O}_{10} \cdot 6 \mathrm{H}_{2} \mathrm{O}(0<\mathrm{x}<1)(\mathrm{O})$ and the two phase mixture of the $\left(\mathrm{NH}_{4}\right)_{3} \mathrm{HGe}_{7} \mathrm{O}_{16} \cdot 6 \mathrm{H}_{2} \mathrm{O}$ mother phase with the $\left(\mathrm{NH}_{4}\right)_{2} \mathrm{HPO}_{4}$ phase $(\bullet)$, respectively. The inserted numbers are n values at $100^{\circ} \mathrm{C}$.

higher angles. This result explicitly indicates that the doped phosphor $\left(0.31 \mathrm{~nm}(\mathrm{IV})^{7}, 0.52 \mathrm{~nm}(\mathrm{VI})^{71}\right)$ replaces the $\mathrm{Ge}\left(0.53 \mathrm{~nm}(\mathrm{IV})^{7}, 0.67 \mathrm{~nm}(\mathrm{VI})^{7}\right)$ site by forming a solid solution. The variation of the sensor output with the logarithm of the $\mathrm{NH}_{3}$ gas concentration was measured by fabricating the $\mathrm{NH}_{3}$ gas concentration cell at $100^{\circ} \mathrm{C}$ and the results are shown in Fig. 1 for the solid solution of $\left(\mathrm{NH}_{4}\right)_{1,4+x} \mathrm{H}_{1-x} \mathrm{Ge}_{7} \mathrm{O}_{16} \cdot 6 \mathrm{H}_{2} \mathrm{O}(\mathrm{O}<\mathrm{x}<1)$, $\left(\mathrm{NH}_{4}\right)_{1.4+\times} \mathrm{H}_{1-x} \mathrm{Ge}_{6,0} \mathrm{P}_{1,0} \mathrm{O}_{16} \bullet 6 \mathrm{H}_{2} \mathrm{O}$ which corresponds to the $\mathrm{P} /(\mathrm{Ge}+$ P) ratio of 0.14 and the two phase mixture of the $\left(\mathrm{NH}_{4}\right)_{3} \mathrm{HGe}_{7} \mathrm{O}_{16}$ - $6 \mathrm{H}_{2} \mathrm{O}$ mother phase with $\left(\mathrm{NH}_{4}\right)_{2} \mathrm{HPO}_{4}$, respectively. The $\mathrm{NH}_{3}$ gas concentration was varied from 200 to $1000 \mathrm{ppm}$ as described in Ref. 6. The theoretical Nernst equation is described as follows ${ }^{6}$ (the detail derivation is described in Ref. 6).

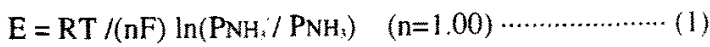

Comparing the ammonia gas sensing characteristics of three sensor cells, the n values obtained with the solid electrolyte of $\left(\mathrm{NH}_{4}\right)_{1.4+\mathrm{x}} \mathrm{H}_{1-\mathrm{x}} \mathrm{Ge}_{6.0} \mathrm{P}_{1.0} \mathrm{O} \cdot \mathrm{H}_{2} \mathrm{O}(0<\mathrm{x}<1)$ shows almost the same value obtained from the Nernst relation(eq. (I) in both before and after the cases where the test and the reference gas compartment was changed vice versa. In addition, when both the test and the reference gas content was maintained at $200 \mathrm{ppm}$, the sensor output for $\left(\mathrm{NH}_{4}\right)_{1.4+x} \mathrm{H}_{1-x} \mathrm{Ge}_{6,0} \mathrm{P}_{1,0} \mathrm{O}_{16} \cdot 6 \mathrm{H}_{2} \mathrm{O}(0<\mathrm{x}<\mathrm{l})$ and the two phase mixture of the $\left(\mathrm{NH}_{4}\right)_{3} \mathrm{HGe}_{7} \mathrm{O}_{16} \cdot 6 \mathrm{H}_{2} \mathrm{O}$ mother phase with $\left(\mathrm{NH}_{4}\right)_{2} \mathrm{HPO}_{4}$ was almost zero, exactly coincided with the theoretical calculation. From the results described above, the ammonia sensor with the solid solution electrolyte of $\left(\mathrm{NH}_{4}\right)_{1.4}+\mathrm{xH}_{1-\mathrm{x}} \mathrm{Ge}_{6.0} \mathrm{P}_{1,0} \mathrm{O}_{16} \cdot 6 \mathrm{H}_{2} \mathrm{O}(0<\mathrm{x}<1)$ was found to be the most suitable component for the ammonia sensing.

The $n$ value for $\left(\mathrm{NH}_{4}\right)_{1.4+x} \mathrm{H}_{1-x} \mathrm{Ge}_{6,0} \mathrm{P}_{1,0} \mathrm{O}_{16} \cdot 6 \mathrm{H}_{2} \mathrm{O}(0<\mathrm{x}<1)$ is 1.1 and the value is almost consistent with the theoretical value of
1.00 as derived from eq. (1). In addition, the time necessary for the attainment of $90 \%$ response is the shortest for the sensor cell with $\left(\mathrm{NH}_{4}\right)_{1,4-x} \mathrm{H}_{3-x} \mathrm{Ge}_{6,3} \mathrm{P}_{0,7} \mathrm{O}_{16} \cdot 6 \mathrm{H}_{2} \mathrm{O}$ and $\left(\mathrm{NH}_{4}\right)_{1,4+x} \mathrm{H}_{1}$. ${ }_{x} \mathrm{Ge}_{6,0} \mathrm{P}_{1.0} \mathrm{O}_{16} \bullet 6 \mathrm{H}_{2} \mathrm{O}(0<\mathrm{x}<1)$ among the sensors examined. Since the solid electrolytes except for the above mentioned two solid electrolytes show a relatively low hardness, the micro gas leakage occurs and elongates the response time as a result of it. From these results, it is easily recognized that the most appropriate sample for the $\mathrm{NH}_{3}$ sensor element is the solid solution of $\left(\mathrm{NH}_{4}\right)_{1,4+x} \mathrm{H}_{1-x} \mathrm{Ge}_{6,1} \mathrm{P}_{1,1} \mathrm{O}_{16} \bullet 6 \mathrm{H}_{2} \mathrm{O}(0<x<1)$.

With the increase of the $\mathrm{P}$ amount in the solid solution, the Vickers hardness monotonously increases and shows a maximum value of 108 at the $\mathrm{P} /(\mathrm{Ge}+\mathrm{P})$ ratio of 0.14 . Further $\mathrm{P}$ mixing results in the formation of $\left(\mathrm{NH}_{4}\right)_{2} \mathrm{HPO}_{4}$ as a secondary phase and a considerable reduction in Vickers hardness was observed. The harder the solid electrolyte pellet is, the lesser the gas leakage occurs. Therefore, the theoretical $n$ value is obtained for the

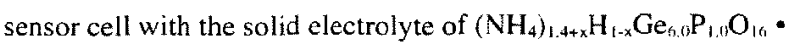
$6 \mathrm{H}_{2} \mathrm{O}(0<x<1)$ with the $\mathrm{P} /(\mathrm{Ge}+\mathrm{P})$ ratio of 0.14 . The sample with lower hardness shows $\mathrm{n}$ value higher than 1.0 , indicating that the $\mathrm{NH}_{3}$ gas leakage occurs in the $\mathrm{NH}_{3}$ gas concentration cell from the compartment of higher in the $\mathrm{NH}_{3}$ content to the lower compartment.

\section{CONCLUSION}

An ammonia gas sensing performance was greatly improved by partially substituting the germanium site in ammonium hydrogermanate for phosphor. The phosphor doping results in a considerable enhancement of the relative density and also mechanical strength of the solid electrolyte ceramics and contributes greatly to realizing a rapid and theoretical response, which is essential for practical sensors.

\section{Acknowledgements}

The present work was partially supported by a Grant-in-Aid for Scientific Research No.09650905 from The Ministry of Education, Science, Sports and Culture. This work was also supported by Yazaki Memorial Foundation for Science and Technology.

(Manuscript received Feb.10, 2000, rivised April.17, 2000)

\section{References}

(1) N. Miura and W. L. Worrell, A solid-state proton conductor sensor with ammonia sensitivity at room temperature. Chem. Lert. 1987. 319

(2) N. Miura and W. L. Worrell, Sensing characteristics of a solid-state ammonia sensor at ambient temperatures, Solid State lonics. 27, 175 (1988).

(3) J. Kleperis, G. Vaivars, G. Bajars, A. Krancvskis, A. Lusis, and G. Vitins, Solid proton conductors as room temperature gas sensors. Sen.s. Actuators, B13-14, 269 (1993).

(4) T. Tsurumi, H. Ikawa, M. Ishimori, K. Urabe, and S. Udagawa. Experimental assembling of gas cells using beta/beta"-alumina type $\mathrm{NH}_{4}{ }^{+}$-gallates electrolytes, Srid Stale lonics, 21, 31 (1986).

(5) N. Imanaka. S. Tamura, and G.Adachi, Ammonia sensor based on ionically exchanged $\mathrm{NH}_{4}{ }^{+}$-gallate solid electrolytes, Electrochem. and Sulid-State Letters, 1, 282 (1998).

(6) N. Imanaka, S. Yoshikawa, T. Yamamoto and G. Adachi. Ammonia sensing characteristics of solid electrolytes based on ammonium hydrogermanate, Electrochem. and Solid Shate Letters, 2. 352 (1999).

(7) R. D. Shannon. Revised effective ionic radii and systematic studies of interatomic distances in halides and chalcogenides. Actu $\mathrm{Cn}$ nt.. A32. $751(1976)$. 